\title{
Comparison of the Quality Characteristics of 4 Albinos Tea*
}

\author{
Ronglin Li ${ }^{1}$, Zhengzheng Li ${ }^{1}$, Yiyang Yang ${ }^{1}$, Hao Yuan'², Yunlong Kong ${ }^{3}$ \\ ${ }^{1}$ Institute of Horticulture Science, Jiangsu Academy of Agricultural Science, Nanjing, China; ${ }^{2}$ Institute of Machinery Engineering, \\ Jiangsu University, Zhenjiang, China; ${ }^{3}$ Liyang Xinlong Ecology Agriculture Develop Company Limited, Changzhou, China. \\ Email: 18001rl@163.com
}

Received July 23 ${ }^{\text {rd }}, 2013$; revised August 23 ${ }^{\text {rd }}, 2013$; accepted August $31^{\text {st }}, 2013$

Copyright (C) 2013 Ronglin Li et al. This is an open access article distributed under the Creative Commons Attribution License, which permits unrestricted use, distribution, and reproduction in any medium, provided the original work is properly cited.

\begin{abstract}
The made tea quality and chemical characteristics of 4 albinos cultivars were investigated. It shows that constitutes of micro-elements, contents of polyphenols and total amino acids in 4 samples are much different due to the biological diversity. The DPPH free radicals scavenging ability of the 4 albinos tea is also different. The free radicals scavenging rate has a significant positive correlation to the content of total polyphenols, total catechins, as well as $\mathrm{C}$, $\mathrm{CG}$, GCG, EGCG, but there is no positive relationship to the content of $\mathrm{Zn}, \mathrm{Se}$.
\end{abstract}

Keywords: Albino's Tea; Chemical Characteristics; Diversity

\section{Introduction}

In recent years, a special kind of tea product called albinos tea is becoming favorite in tea market in China. The basic characters of tea are that the fresh leaves appear pale green or bright yellow i.e, the so called albinos [1-3]. Albinos phenomenon is widely present at high plants. The most ordinary albinos phenomenon is the leaf color metamorphosis of ornamental plants whose pie-baldness leaves are regarded as a character to admire [4]. Albinos may occur in lots of crops, but it is usually treated as a physiology disease $[5,6]$. However, an important fact is, though albinos in tea plant is also a disease or a leaf metamorphosis, it has created a great market value, so it is worth paying much attention $[1,2,7,8]$.

Albinos tea plant was observed even in Song dynasty in China; the emperor Songhuizong indicated in his famous book "Da Guan Cha Lun" that albinos tea plant was a rare one; there were only a few of albinos tea plants growing in the hill, but it can be made of a delicious tea if a proper processing method was taken $[1,2,8]$. We don't know why such a great quality tea should disappear in history, fortunately in the 90 s of last century this special and rare tea variety was rediscovered in Anji county, Zhejiang province of China again. At first it was

*Founded by Jiangsu Province agricultural innovation CX (12)3082, Jiangsu Province science and technology support plan items BE 20113246, SBE20130495. only reproduced and grown in Anji county, but no sooner it spread through the most tea product districts in China due to its special quality characters, great economical and important scientific value [1-3].

Since the albinos tea was rediscovered and quickly spread, researchers noticed that actually there are also a few of other albinos tea varieties, such as Huangjinya from Ningpo of Zhejiang province, Baijiguan from Wuyishan of Fujian province $[2,3,9,10]$.

There are some common characteristics for these different albinos tea varieties, because they distribute far away from each other, they get much different characters in made tea. Until now except for part of the biology characters of the albinos tea that has been investigated, there is little information on made tea derived of these varieties $[1,2,9,10]$.

We have collected albinos tea varieties for years to learn more information on made tea of these albinos tea resource and prompt its spread and development, explore its health value. We choose 4 of the albinos tea plants picking shoots and processing made tea this spring. The chemical characters of the made tea were checked as following.

\section{Materials and Methods}

\subsection{Facilities}

Atomic absorption spectrometer, Zeeman700, Jena, Ger- 
many. Centrifuge Beckmancoulter-Optima-L, US. UVVis Spectrometer, Mapada Double Beam, US. HPLC, Angilent 6890A, US.

\subsection{Samples Preparation}

Tea shoots, two and a bud, picked from albinos tea plants growing in experiment garden were processed by green tea processing method, de-enzyme in roller, then rolling and drying. The 4 varieties was No. 1. Baiyecha 1, introduced from Anji, No. 2. Huangjinya, introduced from Ningpo, No. 3. Anji yellow tea, introduced from Anji, No. 4. Suyuhuang, introduced from Wuxi. Samples were prepared and also labeled as No. 1, 2, 3, 4 albinos tea respectively.

Color of fresh leaves of the 4 kinds of albino's tea was record according to Pantone Formula guides (uncoated). Leaves were picked and washed with clean water, drying with soft paper carefully, then put on the black table in sensory evaluation room, comparing with Pantone cards $[7,8]$.

\subsection{Sensory Evaluation}

Sensory evaluation refers to method of GB/T23776-2009, $3 \mathrm{~g}$ of tea sample was put into a $150 \mathrm{~mL}$ cup, infused with $150 \mathrm{ml}$ boiling water for $5 \mathrm{mins}$, then evaluating the quality through senses based on the method of famous tea evaluation. The total quality values were calculated as following.

$$
\text { Quality value }=\sum(\text { sensory values } \times \text { weight })
$$

The five sensory indicators weight is: shape $25 \%$, color of tea soup $10 \%$, fume $25 \%$, taste $30 \%$, residue leaves $10 \%$ respectively, sensory values were given by tea sensory evaluation technician.

\subsection{Chemical Analysis}

The main components water extract, amino acid, caffeine, polyphenols and catechins analysis is carried out with methods described in literatures.

Elements, atomic absorption spectrometer method [9], water extracts, fully volume method, ISO9768-1997, tea polyphenols, tartaric acid ferrous colorimetric method. GB/T8813-2002, total amino acid, Indenes three ketone colorimetric method GB/T8314-2002, catechin constitutes, HPLC method [10].

\subsection{Anti-Oxidant Power of Albino's Tea}

Because of its relatively low content of polyphenols and high content of amino acid, we think the health function of the albinos tea for free radicals screen ability should be reevaluated., to do this the DPPH method was selected [11], $1 \mathrm{~g}$ of sample (passing 60 times smash) was ex- tracted with $100 \mathrm{ml}$ water for $30 \mathrm{~min}$ at a water bath of $90^{\circ} \mathrm{C}$, then centrifuge at $4000 \mathrm{~g}$, residue was discard. At $10 \mathrm{ml}$ plastic tube adding to the DPPH $(0.01 \%, \mathrm{~W} / \mathrm{V}$ in ethanol), ethanol $(100 \%)$ and tea extracts respectively as following table, bathing in water of $25^{\circ} \mathrm{C}$ for $30 \mathrm{~min}$, then detecting the absorption at $515 \mathrm{~nm}$, with ethanol as blank, repeat 3 times for each treatments.

\begin{tabular}{ccccc}
\hline Tube Num. & 1 & 2 & 3 & 4 \\
\hline Ethanol & 3 & $\mathrm{~A}_{0}$ & $\mathrm{~A}_{\mathrm{j}}$ & $\mathrm{A}_{\mathrm{i}}$ \\
DPPH & 0 & 1 & 2 & 1 \\
Tea extracts & 0 & 0 & 1 & 1 \\
\hline
\end{tabular}

Scanning rate of DPPH is calculated as following:

$$
\text { Scanning } \operatorname{rate}(\%)=\left(1-\left(\left(\mathrm{A}_{\mathrm{i}}-\mathrm{A}\right) / \mathrm{A}_{0}\right)\right) \times 100 \% \text {. }
$$

\subsection{Statistical Analysis}

Data collected from this experiment were subject to statistical analysis with SPSS 13.0 and EXCEL 2003, multiple comparison was carried out to examine the significant differences among the main characteristics test by $\operatorname{LSD}(\mathrm{P}<0.05)$.

\section{Results and Discussion}

\subsection{Color Description of 4 Albinos Tea Leaves}

Panton color code: No. 1, 587C, yellow 2, $9+$ Rf. Blue $0.2+$ Trans white 96.9; No. 2, 397C, yellow 95.5 + green $3.0+$ black 1.5; No. 3, 584C, yellow $23.4+$ Rf. Blue 1.6 + Trans white 87.5 , No. 4, 391C, yellow $88.2+$ green 5.9 + black 5.9 .

According to the Panton color code, the 4 albinos tea's nature color was described as above. The two kinds of Anji albinos tea No. 1, No. 3 can generally described as "white tea", in spring day their fresh leaves appears white with a vary light green mixed with a light yellow under the sunshine, between the two kinds of Anji albinos tea, the Baiyecha 1 seems to be a really "white tea" while the Anji yellow tea's leaves show a little yellow characters, though it is not so oblivious $[2,3]$.

On the other side the albinous tea No. 2, Huangjinya from Ningpo Zhejiang province, the No. 4 Suyuhuang from Wuxi Jiangsu province is really the yellow tea, their leaves show a outstanding characters of brilliant yellow $[9,10]$.

\subsection{Sensory Evaluation Results}

Sensory evaluation data Table 1 showed that the shape values of the 4 albinos tea is nearly the same, because the 4 albinos tea were grown in the same condition, their 
growing speed is also nearly the same, so the shoot tenderness of the 4 albinos tea is in the same class, therefore all can get a good shape in made tea. When processed in a same way, may be the reason is the same that the 4albinos tea can't be said better from one in their flavor too.

Values of soup color of the 4 albinos tea has not much difference too, this means in spite of the different of their leaf color, which is the reflection of the sediment consists, may be in the whole it does not affects the soup color for the reason that the soup color of green tea may affected mainly by the processing $[12,13]$.

In this experiment we find the only different of the 4 albinos tea in sensory taste is their fume. Factors on which the made tea fume is depend are complicated [12-15], it needs a further study, here we only indicate that the fume values of No. 2, No. 4, the yellow leaves varieties is higher than that of No. 1, No. 3, the white leaves varieties.

Finally the total values of the sensory evolution score is No. $2>$ No. $4>$ No. $1>$ No. 3 , but there is no statistical difference between them $(\mathrm{P}<0.05)$, we may not able to tell the different of made tea quality just by the albinos features yet.

\subsection{Chemical Analysis Results}

Results of elements analysis in Table 2 showed that the 4 albinos tea has a obvious different character in mi- cro-elements accumulation, content of the important nutritional micro elements ferrous (Fe) and zinc ( $\mathrm{Zn})$ in No. 1 the Anji Baiyecha 1 is much higher then that of others, it also has a relativity high content of selenium $(\mathrm{Se})$, we will find that the amino acid content (see Table 3 ) in Anji Baiyecha 1 is also much higher, from these results we can say the Baiyecha 1 is the most valuable tea of the 4 tested albinos tea viewed in nutrition.

As for the other elements no a general variation tendency is found, there is not statistics difference of magnesium, $(\mathrm{Mg})$ content between the albinos tea No. 1 , No. 2 and No. 4 except for that of No. 3 is a little lower, but content of calcium $(\mathrm{Ca})$, and manganese $(\mathrm{Mn})$ among the 4 albinos tea is oblivious different in statistics in the confidence level of $0.05 \%$, this results further reveals the genetically biodiversity of albinos tea. Recent years there are researchers trying to trace the origin of the protection of geographical origin products based on the distribution of mineral elements, according to this research may be it is difficult at least for albino's tea, because the distribution of mineral elements is mainly determined by patterns of inheritance $[16,17]$.

Table 3 showed that all of the 4 albinos tea has a high level of amino acids though the differences of total amino acid between the 4 albinos tea is significant, the most is the No. 2, Huangjinya from Ningbo Zhejiang province, its amino acid reach at $10.13 \%$ (in dry weight), even the relatively lower one, the No. 3, Anji huangcha, its amino acid $8.10 \%$ (in dry weight), is obvious higher

Table 1. Sensory evaluation values.

\begin{tabular}{|c|c|c|c|c|c|c|}
\hline & Shape & Soup color & Fume & Flavor & Residue leaves & Total values \\
\hline Weight, \% & 25 & 10 & 25 & 30 & 10 & 100 \\
\hline No. 1 & $88.00 \pm 1.41^{\mathrm{a}}$ & $79.50 \pm 0.71^{\mathrm{a}}$ & $85.00 \pm 1.41^{\mathrm{a}}$ & $88.00 \pm 0.00^{\mathrm{a}}$ & $84.50 \pm 2.12^{\mathrm{a}}$ & $86.05 \pm 0.85^{\mathrm{a}}$ \\
\hline No. 2 & $89.50 \pm 0.71^{\mathrm{a}}$ & $82.00 \pm 0.00^{\mathrm{a}}$ & $88.50 \pm 0.71^{b}$ & $86.50 \pm 0.71^{\mathrm{a}}$ & $88.00 \pm 0.00^{\mathrm{a}}$ & $87.45 \pm 0.21^{\mathrm{a}}$ \\
\hline No. 4 & $89.5 \pm 0.71^{\mathrm{a}}$ & $80.00 \pm 1.41^{\mathrm{a}}$ & $89.00 \pm 2.83^{b}$ & $86.00 \pm 0.00^{\mathrm{a}}$ & $85.00 \pm 2.83^{\mathrm{a}}$ & $86.93 \pm 1.31^{\mathrm{a}}$ \\
\hline
\end{tabular}

Note: No. 1, Baiyecha 1; No. 2, Huangjinya; No. 3, Anji yellow tea; No. 4. Suyuhuang.

Table 2. Elements in albinos tea (mg/kg).

\begin{tabular}{|c|c|c|c|c|c|c|c|}
\hline & $\mathrm{Fe}$ & $\mathrm{Mn}$ & $\mathrm{Zn}$ & $\mathrm{Ca}$ & $\mathrm{Mg}$ & $\mathrm{Cu}$ & $\mathrm{Se}$ \\
\hline & $\mathrm{mg} / \mathrm{kg}$ & $\mathrm{mg} / \mathrm{kg}$ & $\mathrm{mg} / \mathrm{kg}$ & $\mathrm{mg} / \mathrm{kg}$ & $\mathrm{mg} / \mathrm{kg}$ & $\mathrm{mg} / \mathrm{kg}$ & $\mathrm{mg} / \mathrm{kg}$ \\
\hline No. 1 & $451.0 \pm 4.1^{\mathrm{a}}$ & $563.4 \pm 8.9^{\mathrm{a}}$ & $302.0 \pm 3.0^{\mathrm{a}}$ & $231.0 \pm 2.2^{\mathrm{a}}$ & $169.9 \pm 2.2^{\mathrm{a}}$ & $14.63 \pm 0.51^{\mathrm{a}}$ & $0.182 \pm 0.005^{\mathrm{a}}$ \\
\hline No. 2 & $309.9 \pm 6.0^{\mathrm{d}}$ & $829.6 \pm 9.5^{\mathrm{d}}$ & $107.6 \pm 1.8^{d}$ & $315.4 \pm 3.2^{\mathrm{d}}$ & $80.76 \pm 2.33^{b}$ & $16.80 \pm 1.04^{\mathrm{ab}}$ & $0.166 \pm 0.007^{\mathrm{ab}}$ \\
\hline No. 4 & $230.5 \pm 3.6^{b}$ & $647.9 \pm 5.7^{\mathrm{b}}$ & $103.9 \pm 1.5^{b}$ & $265.2 \pm 4.3^{b}$ & $172.4 \pm 2.0^{\mathrm{a}}$ & $16.54 \pm 0.86^{\mathrm{a}}$ & $0.170 \pm 0.005^{\mathrm{a}}$ \\
\hline
\end{tabular}

Note: No. 1, Baiyecha 1; No. 2, Huangjinya; No. 3, Anji yellow tea; No. 4, Suyuhuang. 
than the average amino acid level which is about 3\% $5 \%$ in ordinary green tea, in fact the high content of amino acid in albinos tea, is the mainly characters as well as the reason of why it is worthy to develop.

The caffeine content in No. 2, Huangjinya is a little lower, but in general the caffeine level is normal in the 4 albinos tea, their coffine content is normal. Polypnenols content in No. 3, No. 4 reaches at the average level, while the No. 1, No. 2, No, both of them derived from Anji, is lower comparing to the other reports.

Results of catechins analysis (Table 4) indicated that in spite of the difference in quantity of polyphenols (Table 3 ), the statistics significant difference of total catechins content between the 4 albinos samples lacks consistency with the polyphenols, for example there is no statistics significant difference of the contents of polyphenols between the No! Baiyechaland No. 2 Huang- jinya, yet their catechins content is different in statistics, on the other side, there is diffrence of the content of polypheonols between No. 2 Huangjinya, No. 3 Anji yellow tea, but the total contents of the 2 samples has no difference in statistics, this special phenomena need to investigate further, for in most of cases contents of polyphenols can represent the level of catechins $[12,13]$.

According to Table 5, the free radical DPPH clearance rate of the 4 albinos tea is No. $1>$ No. $2>$ No. $3>$ No. 4 , according to Table 6 there is a strong positive correlation between the content of total polyphenols or catechins, EGCG, $\mathrm{ECG}, \mathrm{CG}$ and the free radical clearance rate, but there is no a obvious relationship between the content of water extracts, amino acid and the rate of free radical clearance. Zinc, selenium is regard to be related to the anti-oxides $[18,19]$, but we find no positive relationship between these two elements with radical screening in this study.

Table 3. Organic contents in albino's tea (\%).

\begin{tabular}{|c|c|c|c|c|}
\hline Sample & Water extracts & Tea polyphenols & Amino acid & Caffeine \\
\hline No. 1 & $41.88 \pm 0.39^{\mathrm{a}}$ & $16.87 \pm 0.55^{\mathrm{a}}$ & $9.916 \pm 0.457^{\mathrm{a}}$ & $3.826 \pm 0.216^{\mathrm{a}}$ \\
\hline No. 2 & $40.82 \pm 0.97^{\mathrm{a}}$ & $17.66 \pm 0.64^{\mathrm{a}}$ & $10.13 \pm 0.34^{\mathrm{b}}$ & $2.873 \pm 0.146^{b}$ \\
\hline No. 3 & $40.88 \pm 1.33^{\mathrm{a}}$ & $19.95 \pm 0.53^{\mathrm{cd}}$ & $8.090 \pm 0.257^{c}$ & $3.554 \pm 0.155^{\mathrm{c}}$ \\
\hline No. 4 & $38.76 \pm 0.79^{b}$ & $23.22 \pm 0.47^{b}$ & $8.772 \pm 0.284^{\mathrm{d}}$ & $3.241 \pm 0.039^{\mathrm{d}}$ \\
\hline
\end{tabular}

Note: No. 1, Baiyecha 1; No. 2, Huangjinya; No. 3, Anji yellow tea; No. 4, Suyuhuang.

Table 4. Tea catechins in different albinos tea $(\mathrm{mg} / \mathrm{g})$.

\begin{tabular}{|c|c|c|c|c|c|c|c|c|c|}
\hline Sample & GC & EGC & $\mathrm{C}$ & $\mathrm{EC}$ & EGCG & GCG & ECG & $\mathrm{CG}$ & Total \\
\hline No 1 & $\begin{array}{l}1.622 \pm \\
0.0105^{\mathrm{d}}\end{array}$ & $\begin{array}{c}15.11 \pm \\
0.210^{\mathrm{b}}\end{array}$ & $\begin{array}{l}8.37 \pm \\
0.085^{\mathrm{b}}\end{array}$ & $\begin{array}{c}7.516 \pm \\
0.118^{\mathrm{a}}\end{array}$ & $\begin{array}{c}59.22 \pm \\
1.675^{\mathrm{d}}\end{array}$ & $\begin{array}{l}0.694 \pm \\
0.0134^{d}\end{array}$ & $\begin{array}{c}21.74 \pm \\
1.075^{\mathrm{a}}\end{array}$ & $\begin{array}{c}0.1540 \pm \\
0.015^{\mathrm{b}}\end{array}$ & $\begin{array}{c}114.6 \pm \\
0.200^{\mathrm{c}}\end{array}$ \\
\hline No 2 & $\begin{array}{c}5.128 \pm \\
0.116^{\mathrm{a}}\end{array}$ & $\begin{array}{c}11.93 \pm \\
0.150^{\mathrm{d}}\end{array}$ & $\begin{array}{c}14.63 \pm \\
0.810^{\mathrm{a}}\end{array}$ & $\begin{array}{c}3.970 \pm \\
0.001^{\mathrm{c}}\end{array}$ & $\begin{array}{c}67.42 \pm \\
1.000^{\mathrm{c}}\end{array}$ & $\begin{array}{c}1.612 \pm \\
0.011^{\mathrm{c}}\end{array}$ & $\begin{array}{c}15.91 \pm \\
1.445^{\mathrm{b}}\end{array}$ & $\begin{array}{c}0.1038 \pm \\
0.0005^{\mathrm{c}}\end{array}$ & $\begin{array}{c}121.4 \pm \\
0.700^{b}\end{array}$ \\
\hline No3 & $\begin{array}{c}3.010 \pm \\
0.005^{\mathrm{b}}\end{array}$ & $\begin{array}{c}12.32 \pm \\
0.320^{\mathrm{c}}\end{array}$ & $\begin{array}{c}13.60 \pm \\
1.185^{\mathrm{a}}\end{array}$ & $\begin{array}{c}4.247 \pm \\
0.074^{\mathrm{b}}\end{array}$ & $\begin{array}{c}71.07 \pm \\
0.940^{\mathrm{b}}\end{array}$ & $\begin{array}{c}3.273 \pm \\
0.075^{\mathrm{a}}\end{array}$ & $\begin{array}{l}13.70 \pm \\
0.880^{\mathrm{bc}}\end{array}$ & $\begin{array}{l}0.161 \pm \\
0.0016^{\mathrm{b}}\end{array}$ & $\begin{array}{l}122 . \pm \\
0.800^{b}\end{array}$ \\
\hline No 4 & $\begin{array}{c}2.543 \pm \\
0.040^{\mathrm{c}}\end{array}$ & $\begin{array}{c}15.94 \pm \\
0.080^{\mathrm{a}}\end{array}$ & $\begin{array}{c}15.38 \pm \\
0.695^{\mathrm{a}}\end{array}$ & $\begin{array}{c}4.108 \pm \\
0.102^{b}\end{array}$ & $\begin{array}{c}80.64 \pm \\
2.115^{\mathrm{a}}\end{array}$ & $\begin{array}{c}2.935 \pm \\
0.087^{\mathrm{b}}\end{array}$ & $\begin{array}{c}11.43 \pm \\
0.915^{\mathrm{d}}\end{array}$ & $\begin{array}{c}0.4994 \pm \\
0.0207^{\mathrm{a}}\end{array}$ & $\begin{array}{c}133.5 \pm \\
0.751^{\mathrm{a}}\end{array}$ \\
\hline
\end{tabular}

Note: No. 1, Baiyecha 1; No. 2, Huangjinya; No. 3, Anji yellow tea; No. 4, Suyuhuang.

Table 5. Anti-oxidation test results.

\begin{tabular}{ccccc}
\hline Sample & No. 1 & No. 2 & No. 3 & No. 4 \\
\hline Free radical clearance rate & $89.81 \pm 0.49^{\mathrm{ab}}$ & $84.94 \pm 1.21^{\mathrm{ab}}$ & $79.57 \pm 0.74^{\mathrm{b}}$ & $74.43 \pm 0.57^{\mathrm{b}}$ \\
\hline
\end{tabular}

Note: No. 1, Baiyecha 1; No. 2, Huangjinya; No. 3, Anji yellow tea; No. 4, Suyuhuang.

Table 6. Correlation between consists and the free radical screen ability of albinos tea.

\begin{tabular}{|c|c|c|c|c|c|c|c|c|c|}
\hline Consists & $\mathrm{GC}$ & EGC & $\mathrm{C}$ & $\mathrm{EC}$ & EGCG & GCG & ECG & $\mathrm{CG}$ & Total \\
\hline Corr. & 0.0595 & 0.1731 & 0.8153 & -0.7560 & 0.9852 & 0.9136 & -0.9686 & 0.7715 & 0.9321 \\
\hline Corr. & \multicolumn{2}{|c|}{-0.2648} & 0.9644 & \multicolumn{2}{|c|}{-0.7438} & -0.3389 & \multicolumn{2}{|c|}{-0.7577} & -0.2074 \\
\hline
\end{tabular}




\section{Conclusions}

Tea as a special drink is viewed as a healthy drink since ancient time [20-22]. It not only contains all kinds of mineral elements which can provide a supplement for every day nutritional need, but also contains a high level of polyphenols which can protect the cardiovascular system from attack by clearing the free radicals. It should be specially indicated that albinos tea with its chloroplastid degeneration at infinite conditions usually contains a high level of amino acids and relatively lower of polyphenols [1-3]. In our present study, the high content of amino acid was confirmed again, yet it is not expected that among the 4 albinos varieties two of them contain both of amino acid and polyphenols in a high level, and tests demonstrated its high content of polyphenols has a positive correlation to the ability of scanning free radicals, which is really valuable and rare. In this way, we will say that drinking a cup of albinos tea is enjoying a really healthy drink $[23,24]$.

Albinos tea with its high content of amino acid taste fresh and mild but no bitter and astringent as we drink ordinary green tea $[25,26]$. In this study we find that even in those of high content of polyphenols in albinos tea, its flavor shows the characters of attractive fragrance and strong mellow taste, which will create attractive effects for those who don't like the bitter and astringent tea. The changeful chrematistics of micro-elements and catechins in albinos tea also provides a multiple choice considering both of the health and edict $[27,28]$.

Chemical or biochemical diversity of albinos tea which derived of the tea biodiversity not only can meet people's extensive demand on taste and health via abundant tea specifications. It also affords diverse enjoyment of tea, and makes tea drinking full of more temperament and interest. Albinos tea with its leaves looks like "jade" that can express beauty to most extent when soaking in glass cup. Rich and colorful tea leaves show us various color, as well as fume, flavor and fine shapes by which a wonderful tea culture can be created [1-3]. Besides in the tea plantation field, the beauty color of tea leaves can be used to set up a touring tea garden $[29,30]$.

\section{REFERENCES}

[1] S. F. Li, S. Y. Chen and H. Cheng, "Physiological and Biochemical Essence of the Extraordinary Characters of Anji Baicha," Journal of Tea Science, Vol. 19, No. 2, 1999, pp. 87-92.

[2] K. R. Wang, "Germplasm Resource of Albinos Tea," The Valuable and Rare Albinos Tea, China Culture and History Press, Beijing, 2005, pp. 19-34.

[3] M. Y. Song, R. F. Ren, T. F. Zhou, et al., "Characteristics of Geology and Geochemistry in Proaucing Area of the Anji White Tea Zhejiang Province," Geoscience, Vol. 22, No. 6, 2008, pp. 924-929.
[4] B. Isabel and L. Rosario, "Mitochondrial DNA Amplification in Albino Plants of Rye, No, Secale cereale L., Regenerated in Vitro," Plant Science, Vol. 176, No. 6, 2013, pp. 722-728.

[5] Y. P. Du and D. Y. Xu, "Inheritance of Albino Seedling Character in Rice," Plant Genetic Resources Science, Vol. 3, No. 1, 2002, pp. 20-22.

[6] S. F. Li, S. Y. Chen and H. Cheng, "Studies on the Staging Albescent Phenomenon in Tea Plants-Observation on the Ultra-Microstructure of the Chloroplast," Journal of Tea Science, Vol. 15, No. 1, 1995, pp. 23-28.

[7] R. L. Li and Y. L. Kong, "Study and Development of Albinos Tea," Journal of Jiangsu Agricultural Sciences, Vol. 38, No. 6, 2010, pp. 12-16.

[8] D. M. Sheng, H. G. Ruan and L. Z. Yu, "All the Ancient China Books about Tea," Zhejiang Photographing Press, Hangzhou, 2008, pp. 89-97.

[9] M. Li, L. J. Zhang and K. R. Wang, "Studies on Characteristics of Illumination Induced Albino Tea Cultivar 'Huangjinya'," Journal of Tea, Vol. 34, No. 2, 2008, pp. 98-102.

[10] K. R. Wang, M. Li and R. F. Wang, "Cultivation and Processing Technology of Illumination Induced Albino Tea," Journal of China Tea, Vol. 37, No. 11, 2008, pp. 15-18.

[11] S. P. Nie, M. Y. Xie and Z. Luo, "Antioxidative Activity Evaluation Study on Tea Polysaccharide by Scavenging DPPH," Food Science, Vol. 27, No. 3, 2006, pp. 34-36.

[12] Y. W. Jiang, "Principle of Tea Processing," Chinese Tea Products Processing, Shanghai Sciences and Technology Press, Shanghai, 2011, pp. 39-67.

[13] Z.-M. Chen, "Tea Characteristics," China Tea Classics, Shanghai Culture Press, Shanghai, 2012, pp. 69-123.

[14] A. B. Jose, F. P. Joaquim, R. C. B. Tavares, et al., "Comparison of Catechins and Aromas among Different Green Teas Using HPLC/SPME-GC," Food Research International, Vol. 31, No. 10, 1998, pp. 729-736. http://dx.doi.org/10.1016/S0963-9969(99)00052-6

[15] F. G. Wen, S. Kanzo, W. Naoharu, et al., "Geranyl 6-O$\beta$-d-Xylopyranosyl- $\beta$-d-Glucopyranoside Isolated as an Aroma Precursor from Tea Leaves for Oolong Tea," Phytochemistry, Vol. 33, No. 6, 1993, pp. 1373-1375. http://dx.doi.org/10.1016/0031-9422(93)85093-7

[16] Y. W. Yuan, Y. Z. Zhang, H. Y. Fu, et al., "Application of Pal-Da Method to Determine the Geographical Origin of Tea Based on Determination of Stable Isotopes and Multi-Elements," Journal of Nuclear Agricultural Sciences, Vol. 27, No. 1, 2013, pp. 47-55.

[17] A. Marcos, A. Fisher, G. Rea, et al., "Preliminary Study Using Trace Element Concentrations and a Chemometrics Approach to Determine the Geographical Origin of Tea," Journal of Analytical Atomic Spectrometry, Vol. 13, No. 6, 1998, pp. 521-525. http://dx.doi.org/10.1039/a708658j

[18] Z. P. Li, P. S. Wu, J. Yu, et al., "Antioxidant Activity in Vitro of Zinc Rich Exopolysaccharide from Ganoderm Applanatum," Chinese Journal of Tropical Crops, Vol. 33, No. 5, 2012, pp. 890-893.

[19] J. X. Cai, X. D. Huang, S. H. Wu, et al., "In Vitro and in 
Vivo Antioxidant Effects of polyphenol in Selenium-Enriched and Germanium-Enriched Inonotus Obliquus," Chinese Agricultural Science Bulletin, Vol. 28, No. 27, 2012, pp. 270-276.

[20] S. R. Sheng, C. F. Jin and X. Q. Yang, "Study on the Scavenging Effects of EGCG and GCG on Singlet Oxygen with ESR Method," Journal Tea Science, Vol. 20, No. 1, 2000, pp. 22-26.

[21] X. Y. Li, X. Q. Yang and B. L. Zhao, "Studies on the Free Radical Scavenging and the Antioxidant Effects of Green Tea Phenol Products (GTP)," Environmental Chemistry, Vol. 11, No. 4, 1992, pp. 13-15.

[22] Y. F. Fan, "Multi-Brand Strategy for Product Orientation," World Standards News, No. 5, 2006, pp. 56-58.

[23] M. Y. Song, T. F. Zhou, J. J. Dai, et al., "Environmental Geochemistry of the Producing Area of the Anji White Tea, Zhejiang Province," Geophysical and Geochemical Exploration, Vol. 33, No. 4, 2009, pp. 444-447.

[24] C. Su, Y. H. Liu and Z. X. Lu, "Protection of Epigallocatechin-3-Gallate on Human Liver Cells from Qxidative Injury," Journal of Anhui Agricultural Sciences, Vol. 37, No. 6, 2009, pp. 2561-2563.

[25] Z. Y. Yang, D. Fang, S. Kazuo, et al., "Identification of
Coumarin-Enriched Japanese Green Teas and Their Particular Flavor Using Electronic Nose," Journal of Food Engineering, Vol. 92, No. 3, 2009, pp. 312-316. http://dx.doi.org/10.1016/j.jfoodeng.2008.11.014

[26] Q. G. Tiu, "Methods and Questions Relative to the Past Researches on Tea Chemistry," Journal of Fujian Agricultural University, Vol. 30, No. 3, 2001, pp. 368-371.

[27] L. Q. Zhang, "Tea Consumption Behavior of Urban Resident Evidence from Beijing Household Survey Data," Journal of China Agricultural University (Social Sciences Edition), Vol. 27, No. 2, 2010, pp. 128-134.

[28] B. H. Zhang and Q. Z. Zhu, "Circulation Status and Development Direction of Tea in China," Tea in Fujian, No. 3, 2006, pp. 33-34.

[29] S. W. Cheng, H. Jing, D. Fox, et al., "Tea Tourism Development in Xinyang, China Stakeholders' View," Tourism Management Perspectives, Vol. 2, No. 3, 2012, pp. 28-34.

[30] Z. Y. Tang, Z. X. Su, N. G. Yang, et al., "Problems in the Development of Mulao Township Eco-Agricultural Tourism," Journal of Mianyang Normal University, Vol. 26, No. 11, 2007, pp. 53-55. 